\title{
INDEKS DEBRIS SEBELUM DAN SESUDAH DILAKUKAN PROMOSI KESEHATAN TENTANG MENYIKAT GIGI PADA MURID SD NEGERI POIGAR
}

\author{
${ }^{1}$ Hermawan, \\ ${ }^{2}$ Adrian Umboh, \\ ${ }^{3}$ Christy Mintjelungan \\ ${ }^{1}$ Kandidat Skripsi Program Studi Pendidikan Dokter Gigi Fakultas Kedokteran \\ ${ }^{2}$ Fakultas Kedokteran Universitas Sam Ratulangi Manado \\ ${ }^{3}$ Program Studi Pendidikan Dokter Gigi Universitas Sam Ratulangi \\ Email: eman_anbu11@yahoo.co.id
}

\begin{abstract}
Health promotion are necessary in case to improve people's behavior in order to avoid health problems, Success of an educator in conveying health promotion topics are determined by many things. one of which is the use of effective media and method, The purpose of this study is to find out child debris index in SD Negeri Poigar before and after the health promotion of toothbrushing, The research method used is pre-experimental with one group pre and posttest approaches that conducted to the $4^{\text {th }} .5^{\text {th }}$ and $6^{\text {th }}$ grade student of SD Negeri Poigar, South Minahasa, The number of samples are taken as much 34 students using total sampling technique, This researh used Wilcoxon statistical analysis test, The result showed that before the health promotion of toothbrushing the early debris index was bad category and after the health promotion of toothbrushing the final debris index is medium category, Wilcoxon analysis test showed value of significance $p=0,00$, This statistical analysis concluded that there was a significant difference between debris index before and after the health promotion of toothbrushing in SD Negeri Poigar students.
\end{abstract}

Keywords: debris index, health promotion.

\begin{abstract}
Abstrak:Promosi kesehatan sangat diperlukan dalam meningkatkan perilaku masyarakat agar terbebas dari masalah-masalah kesehatan. Keberhasilan seorang penyuluh dalam menyampaikan materi promosi kesehatan ditentukan oleh banyak hal, salah satu diantaranya ialah adanya media dan metode promosi kesehatan yang efektif. Tujuan dari penelitian ini ialah untuk mengetahui indeks debris anak SD Negeri Poigar sebelum dan sesudah dilakukan promosi kesehatan tentang menyikat gigi. Metode penelitian yang digunakan ialah metode pra eksperimental dengan pendekatan one group pre and posttest design yang dilakukan pada siswa kelas 4, 5 dan 6 SD Negeri Poigar, Minahasa Selatan. Jumlah sampel yang diambil sebanyak 34 siswa dengan teknik pengambilan sampel yaitu total sampling. Penelitian ini menggunakan uji analisis statistik Wilcoxon. Hasil penelitian menunjukan bahwa sebelum dilakukan promosi kesehatan tentang menyikat gigi indeks debris awal ialah kategori buruk dan setelah dilakukan promosi kesehatan tentang menyikat gigi indeks debris akhir ialah kategori sedang. Hasil uji analisis statistik Wilcoxon ini menunjukan p=0,00. Hasil analisis ini menunjukan terdapat perbedaan yang bermakna antara indeks debris sebelum dan sesudah dilakukan promosi kesehatan tentang menyikat gigi pada murid SD Negeri Poigar.
\end{abstract}

Kata kunci: indeks debris, promosi kesehatan. 
Sehat dan sakitnya seseorang sangat ditentukan oleh perilaku hidup manusia sendiri. Masalah perubahan perilaku sangat terkait dengan promosi kesehatan maka peran promosi kesehatan sangat diperlukan dalam meningkatkan perilaku masyarakat agar terbebas dari masalah-masalah kesehatan. Promosi kesehatan mempunyai peran yang sangat penting dalam proses pemberdayaan masyarakat, yaitu melalu proses pembelajaran dari, oleh, untuk dan bersama masyarakat, agar mereka dapat menolong dirinya sendiri serta mengembangkan kegiatan yang bersumber daya masyarakat, sesuai dengan kondisi sosial budaya setempat dan didukung kebijakan publik yang berwawasan kesehatan. ${ }^{1}$ Menjaga kesehatan gigi merupakan hal yang yang sangat diperlukan sejak dini, namun masih banyak masyarakat yang mengabaikan kesehatan gigi dan mulutnya. Berdasarkan data Riset Kesehatan Dasar (Riskesdas) tahun 2013 prevalensi nasional masalah gigi dan mulut dijumpai sebesar 25,9\%, dan terdapat 14 provinsi mempunyai prevalensi masalah gigi dan mulut di atas angka nasional, termasuk diantaranya ialah provinsi Sulawesi Utara dengan angka prevalensi 31,6\%. Untuk perilaku menyikat gigi dengan benar setelah makan pagi dan sebelum tidur malam, untuk Indonesia ditemukan 2,3\% dengan prevalensi paling rendah untuk kelompok umur 10-14 tahun $(1,7 \%){ }^{2}$ Pada anak usia 9-14 tahun perubahan perilaku tidak hanya dapat dilakukan melalui proses pembiasaan, melainkan harus disertai pula oleh proses perubahan dalam pemahamannya, karena anak-anak pada usia tersebut sudah memiliki pola pikir, pola rasa dan paradigmanya sendiri. Pada usia ini anak sering mempermasalahkan kebiasaankebiasaan tertentu, mengapa mereka harus melakukannya. $^{3} \quad$ Keberhasilan seorang penyuluh dalam menyampaikan materi promosi kesehatan ditentukan banyak hal, salah satu diantaranya ialah adanya media dan metode promosi kesehatan yang efektif.Jenis media yaitu berupa alat-alat peraga dapat dibagi dalam 6 kelompok diantaranya gambar/media grafis berupa leaflet dan gambar alat optik dalam bentuk slide. Metode yang dapat dipergunakan dalam melaksanakan promosi kesehatan dibagi menjadi 8 metode diantaranya ialah metode ceramah dan metode demonstrasi. ${ }^{4}$ Penilaian kebersihan gigi dan mulut menggunakan indeks OHI-S (Oral Hygiene Indeks Simplified) yang merupakan jumlah indeks debris (DI) dan indeks kalkulus (CI). Oral Hygiene Indeks Simplified(OHIS) digunakan untuk menilai hasil dari cara menyikat gigi, menilai kegiatan kesehatan gigi dari masyarakat, serta menilai efek segera dan jangka panjang dari program pendidikan kesehatan gigi. Pada penelitian ini penilaian yang dilakukan ialah indeks debris dengan tidak menilai indeks kalkulus karena promosi kesehatan yang diberikan ialah tentang menyikat gigi dan untuk kalkulus tidak dapat dihilangkan hanya dengan kegiatan menyikat gigi. ${ }^{5,6}$ Berdasarkan data dan uraian di atas peneliti ingin meneliti status debris sebelum dan sesudah dilakukan promosi kesehatan pada murid SD Negeri Poigar. Alasan memilih di SD Negeri Poigar oleh karena berdasarkan pengamatan yang dilakukan penulis saat KKN di kecamatan Sinonsayang, terdapat banyak siswa yang memiliki kebersihan gigi dan mulut yang kurang baik serta belum pernah dilakukan promosi kesehatan tentang menyikat gigi di sekolah ini. Selain itu, UKGS belum dikembangkan di daerah tersebut.

\section{BAHAN DAN METODE PENELITIAN}

Penelitian ini merupakan penelitian Eksperimental yang menggunakan rancangan penelitian Pra Eksperimental One Group Pre and Posttest design dengan pemeriksaan Indeks Debris awal (pretest) dan sesudah dilakukan promosi kesehatan tentang menyikat gigi dengan memeriksa Indeks Debris akhir (posttest). Penelitian ini dilaksanakan di SD Negeri Poigar pada bulan Maret-Oktober 2015. Populasi pada penelitian ini ialah siswa kelas 4, 5 dan 6 SD Negeri Poigar yang berjumlah 40 orang. Besar sampel yang digunakan ialah total sampling. Alat yang digunakan: sikat 
gigi yang sama pada semua responden (sesuai anjuran), kaca mulut, sonde, pinset, nierbecken, masker, handskun, alat tulismenulis, alat peraga berupa phantom gigi, proyektor, laptop, leaflet. Bahan yang digunakan: pasta gigi, alkohol 70\%, air, kapas, tissue.P engambilan data dilakukan dengan mendatangi SD Negeri Poigar di kecamatan Sinonsayang yang telah ditentukan untuk melakukan pengamatan awal dan meminta persetujuan pihak sekolah untuk melakukan penelitian pada siswa-siswa SD sebagai subjek penelitian. Informed consent ditandatangani oleh orang tua siswa untuk mendapat persetujuan orang tua agar dapat dilakukan pemeriksaan gigi pada anak. Pemeriksaan indeks debris awal pada anak dengan posisi duduk dan menggunakan kaca mulut dan sonde. Pemeriksaan dilakukan pada ruang dengan penerangan yang cukup. Setelah dilakukan pemeriksaan indeks debris awal, peneliti memberikan promosi kesehatan tentang menyikat gigi kepada siswa. Seluruh kegiatan ini dibantu oleh tim yang berjumlah 5 orang yang telah dipersiapkan. Indeks debris akhir disertai wawancara terpimpin pada siswa yang sama dilakukan pada hari ke-3.

\section{HASIL PENELITIAN}

Penelitian ini dilakukan pada bulan Maret sampai Oktober di SD Negeri Poigar di desa Poigar 1, kecamatan Sinonsayang, kabupaten Minahasa Selatan, provinsi Sulawesi Utara. Siswa yang bersekolah di sekolah dasar ini sebanyak 73 anak. Sekolah dikepalai oleh seorang kepala sekolah dan memiliki 7 guru, serta memiliki 9 ruangan termasuk ruang guru dan kelas. Subjek yang hendak diteliti untuk penelitian ini berjumlah 40 siswa, namun yang memenuhi kriteria inklusi sebanyak 34 siswa.

Responden terbanyak ialah siswa perempuan yang berjumlah 27 siswa dengan persentase 79,4\%, sedangkan responden siswa laki-laki berjumlah 7 siswa dengan persentase 20,6\%.
Tabel 1. Distribusi karakteristik responden berdasarkan jenis kelamin

\begin{tabular}{ccc}
\hline Jenis Kelamin & $\mathrm{n}$ & $\%$ \\
\hline Laki-laki & 7 & 20,6 \\
Perempuan & 27 & 79,4 \\
Total & 34 & 100 \\
\hline
\end{tabular}

Pada distribusi responden berdasarkan usia, subjek penelitian yang berusia 10 tahun sebanyak 16 siswa dengan persentase 47,1\%, diikuti usia 9 tahun sebanyak 10 siswa dengan persentase $29,4 \%$, usia 11 tahun sebanyak 6 siswa dengan persentase $17,6 \%$ dan usia 12 tahun sebanyak 2 siswa dengan persentase $5,9 \%$.

Tabel 2. Distribusi karakteristik responden berdasarkan usia

\begin{tabular}{cll}
\hline $\begin{array}{c}\text { Usia } \\
\text { (tahun) }\end{array}$ & $\mathrm{n}$ & $\%$ \\
\hline 9 & 10 & 29,4 \\
10 & 16 & 47,1 \\
11 & 6 & 17,6 \\
12 & 2 & 5,9 \\
Total & 34 & 100 \\
\hline
\end{tabular}

Dari hasil pemeriksaan indeks debris sebelum dilakukan promosi kesehatan tentang menyikat gigi pada siswa, didapatkan hasil bahwa tidak ada siswa yang memiliki indeks debris untuk kategori baik, sedangkan hanya 8 siswa yang memiliki indeks debris pada kategori sedang (23,5\%) dan 26 siswa yang memiliki indeks debris untuk kategori buruk (76,5\%).

Tabel 3. Hasil pemeriksaan indeks debris sebelum promosi kesehatan

\begin{tabular}{ccc}
\hline Kategori & $\mathrm{n}$ & $\%$ \\
\hline Baik & 0 & 0 \\
Sedang & 8 & 23,5 \\
Buruk & 26 & 76,5 \\
Total & 34 & 100
\end{tabular}

Berdasarkan data hasil pemeriksaan indeks debris sesudah dilakukan promosi kesehatan tentang menyikat gigi, maka 
didapatkan hasil yaitu sebanyak 7 siswa dengan indeks debris untuk kategori baik dengan persentase 20,6\%, sebanyak 27 siswa dengan indeks debris untuk kategori sedang dan tidak ada siswa dengan indeks debris untuk kategori buruk.

Tabel 4. Hasil pemeriksaan indeks debris sesudah promosi kesehatan

\begin{tabular}{lcc}
\hline Kategori & $\mathrm{n}$ & $\%$ \\
\hline Baik & 7 & 20,6 \\
Sedang & 27 & 79,4 \\
Buruk & 0 & 0 \\
Total & 34 & 100 \\
\hline
\end{tabular}

Hasil analisis antara indeks debris sebelum dilakukan promosi kesehatan dan sesudah dilakukan promosi kesehatan menunjukan bahwa sebelum dilakukan promosi kesehatan belum didapati siswa yang memiliki indeks debris dengan kategori baik, namun sesudah dilakukan promosi kesehatan terdapat 7 siswa yang memiliki indeks debris dengan kategori baik. siswa dengan indeks debris kategori sedang sebelum dilakukan promosi kesehatan terdapat 8 siswa dan sesudah dilakukan promosi kesehatan bertambah menjadi 27 siswa. Siswa dengan indeks debris kategori buruk sebelum dilakukan promosi kesehatan merupakan yang terbanyak dengan total 26 siswa, namun sesudah dilakukan promosi kesehatan sudah tidak ditemukan lagi siswa dengan indeks debris kategori buruk.

Tabel 5. Hasil indeks debris sebelum dan sesudah

\begin{tabular}{lcccc}
\hline Indeks & $\begin{array}{l}\text { Sebelum } \\
\text { promosi } \\
\text { kesehatan }\end{array}$ & \multicolumn{3}{c}{$\begin{array}{l}\text { Sesudah } \\
\text { promosi } \\
\text { kesehatan }\end{array}$} \\
\cline { 2 - 5 } Debris & $\mathrm{n}$ & $\%$ & $\mathrm{n}$ & $\%$ \\
Baik & 0 & 0 & 7 & 20,6 \\
Sedang & 8 & 23,5 & 27 & 79,4 \\
Buruk & 26 & 76,5 & 0 & 0 \\
Total & 34 & 100 & 34 & 100 \\
\hline
\end{tabular}

Pada indeks debris sebelum dilakukan promosi kesehatan tentang menyikat gigi didapatkan nilai rerata sebesar 2,01, sedangkan untuk indeks debris sesudah dilakukan promosi kesehatan tentang menyikat gigi diperoleh nilai rerata sebesar 0,71.Dilihat dari nilai $\mathrm{p}=0,00$ dengan demikian probabilitas lebih kecil dari 0,05 $(\mathrm{p}<0,05)$, sehingga $\mathrm{H}_{0}$ ditolak dan $\mathrm{H}_{1}$ diterima. Dengan demikian hasil ini menunjukkan bahwa ada perbedaan bermakna antara indeks debris sebelum dilakukan promosi kesehatan tentang menyikat gigi dan indeks debris sesudah dilakukan promosi kesehatan tentang menyikat gigi.

Tabel 6. Perbandingan rerata indeks debris sebelum promosi kesehatan dan nilai rerata indeks debris sesudah promosi kesehatan.

\begin{tabular}{llll}
\hline \multicolumn{1}{c}{$\mathrm{n}$} & & $\begin{array}{l}\text { Rerata } \pm \\
\text { s.d }\end{array}$ & $\begin{array}{l}\mathrm{P} \\
\text { value }\end{array}$ \\
\hline $\begin{array}{l}\text { Indeks debris } \\
\text { sebelum promosi } \\
\text { kesehatan }\end{array}$ & 34 & $2,01 \pm 0,32$ & \\
$\begin{array}{l}\text { Indeks debris } \\
\text { sesudah promosi } \\
\text { kesehatan }\end{array}$ & 34 & $0,71 \pm 0,15$ & 0,00 \\
\hline
\end{tabular}

Hasil dari pengukuran kuesioner menunjukkan nilai dari seluruh responden berada dalam kategori baik, yaitu $>15$ point, sehingga dapat dikatakan seluruh responden mengikuti dengan baik semua instruksi yang diberikan dalam promosi kesehatan.

Tabel 7. Penilaian promosi kesehatan menggunakan kuesioner

\begin{tabular}{llll}
\hline Interval & Kategori & $\mathrm{n}$ & $\%$ \\
\hline$>15$ & Baik & 34 & 100 \\
$<15$ & Kurang & 0 & 0 \\
\hline
\end{tabular}

\section{BAHASAN}

Pada penelitian ini peneliti ingin mengetahui indeks debris sebelum dan sesudah dilakukan promosi kesehatan tentang menyikat gigi pada siswa kelas 4, 5 dan 6 SD Negeri Poigar. Peneliti memberikan promosi kesehatan tentang 
tujuan menyikat gigi, pemilihan sikat gigi yang baik dan benar, teknik menyikat gigi menggunakan teknik roll, menyikat gigi minimal 2 menit dan dilakukan 2x sehari sesudah makan pagi dan sebelum tidur serta penggunaan pasta gigi yang mengandung fluor. Penelitian ini merupakan penelitian pra eksperimental tanpa adanya kelompok kontrol, sehingga pengambilan data dilakukan dua kali yaitu sebelum dilakukan promosi kesehatan tentang menyikat gigi dan sesudah dilakukan promosi kesehatan tentang menyikat gigi. Pada penelitian ini didapatkan subjek penelitian sebanyak 34 siswa, yang terdiri dari 7 siswa laki-laki (20,6\%) dan 27 siswa perempuan (79,4\%). Data ini dapat dilihat pada tabel 1 . Berdasarkan hasil penelitian didapatkan nilai rerata indeks debris sebelum dilakukan promosi kesehatan tentang menyikat gigi sebesar 2,01 dengan kategori buruk dan setelah diberikan promosi kesehatan tentang menyikat gigi nilai rerata berkurang menjadi 0,71 dengan ketegori sedang. Dari hasil uji statistik Wilcoxon signed rank test menyatakan terdapat perbedaan yang bermakna antara nilai indeks debris awal dan nilai indeks debris akhir. Setelah dilakukan promosi kesehatan tentang menyikat gigi sebanyak 34 siswa indeks debrisnya menjadi lebih rendah, sehingga didapatkan nilai $\mathrm{P}=0,00$ dengan probabilitas lebih kecil dari 0,05 $(\mathrm{p}<0,05)$. Berdasarkan hasil ini maka $\mathrm{H}_{0}$ ditolak dan $\mathrm{H}_{1}$ diterima karena terdapat perbedaan yang bermakna antara indeks debris sebelum dan sesudah dilakukan promosi kesehatan tentang menyikat gigi pada siswa kelas 4, 5 dan 6 SD Negeri Poigar. Penurunan indeks terjadi karena seluruh siswa mengikuti instruksi atau anjuran yang diberikan dalam promosi kesehatan yang dapat dilihat pada tabel 7. Penurunan ini disebabkan karena peneliti memberikan promosi kesehatan tentang menyikat gigi sehingga dapat merubah atau menambah pemahaman siswa tentang pentingnya menjaga kesehatan gigi dan mulut melalui proses menyikat gigi yang baik dan benar serta dapat merubah perilaku siswa dalam menjaga kesehatan gigi dan mulutnya. ${ }^{3}$ Hasil penelitian ini sejalan dengan penelitian yang pernah dilakukan Sari di MI At-Taufiq Lakarsantri Surabaya yaitu nilai rerata indeks OHI-S awal sebesar 1,76 menjadi 1,29 dengan tidak menunjukan pengaruh yang signifikan terhadap nilai indeks kalkulus. ${ }^{7}$ Penelitian yang hampir sama juga pernah dilakukan Putri di SD Desa Padang Loang Kecamatan Patampanua dengan nilai rerata indeks plak awal sebesar 3,55 menjadi 1,28 setelah diberikan promosi kesehatan.8 Proses belajar yang diberikan melalui kegiatan promosi kesehatan tentang menyikat gigi menggunakan metode dan media yang tepat, sehingga siswa dapat mengerti dan mempraktekannya dalam kesehariannya. Hal ini sesuai dengan yang dikemukakan Notoatmodjo yaitu ceramah merupakan metode yang baik digunakan pada kelompok besar (lebih dari 15 orang) dengan tingkat pendidikan tinggi maupun rendah. ${ }^{9}$ Penelitian yang dilakukan Ilyas di SD Desa Padang Loang Kecamatan Patampanua juga menunjukan metode demonstrasi merupakan metode yang efektif digunakan dalam promosi kesehatan pada siswa Sekolah Dasar. ${ }^{8}$ Selain itu penelitian yang dilakukan Nurhidayat di SD Negeri Sukorejo juga menunjukan media powerpoint lebih efektif daripada flipchart dalam meningkatkan pengetahuan kesehatan gigi dan mulut anak. ${ }^{10}$ penggunaan leaflet yang dibagikan saat selesai ceramah juga memperkuat pesan yang disampaikan sehingga menambah kepedulian siswa dalam menjaga kesehatan gigi dan mulut. ${ }^{11,12}$

\section{SIMPULAN}

Berdasarkan penelitian di Sekolah Dasar Negeri Poigar, maka dapat disimpulkan bahwa:

1. Indeks debris sebelum dilakukan promosi kesehatan tentang menyikat gigi ialah 2,01 dengan kategori yaitu buruk.

2. Indeks debris sesudah dilakukan promosi kesehatan tentang menyikat 
gigi ialah 0,71 dengan kategori yaitu sedang.

3. Terdapat perbedaan yang bermakna antara rerata indeks debris sebelum dilakukan promosi kesehatan dan sesudah dilakukan promosi kesehatan tentang menyikat gigi pada murid SD Negeri Poigar yang diuji menggunakan uji statistik dengan nilai $\mathrm{P}=0,00$

\section{SARAN}

1. Perlu adanya upaya berkelanjutan dari tenaga kesehatan kedokteran gigi untuk terus memberikan informasi tentang perlunya menjaga kesehatan gigi dan mulut melalui kegiatan menyikat gigi kepada siswa sekolah dasar.

2. Perlu adanya upaya berkelanjutan antara pihak sekolah dan tenaga kesehatan gigi terutama dalam pengadaan UKGS agar siswa-siswa sekolah dasar bisa menjaga kesehatan gigi dan mulut dengan baik dan benar.

\section{DAFTAR PUSTAKA}

1. Supari SF. Pedoman pelaksanaan promosi kesehatan di puskesmas. Jakarta: Menteri Kesehatan Republik Indonesia, 2007; p. 3.

2. Badan Penelitian dan Pengembangan Kesehatan. Riset Kesehatan Dasar (RISKESDAS) 2013. Jakarta: Kementerian Kesehatan RI, 2013; p. 110-9.

3. Setyawan IS, Supardono AMZ, Nuryantohadi. Pendidikan budi pekerti. Jakarta: PT Gramedia Widiasarana Indonesia, 2008; p. 2.

4. Purnama SJ. Media dan metode penyuluhan yang efektif bagi penyuluh kesehatan. [diakses 11april2015] Diunduh dari:

http: //badandiklat.jatengprov.go.id/ index.php?p=wi\&m=dt\&id=64.

5. Notohartojo IT, Halim FXS. Gambaran kebersihan mulut dan gingivitis pada murid Sekolah Dasar di puskesmas Sepatan Kabupaten Tangerang. Media Litbang Kesehatan 2010;20(4):180-1.

6. Oktavilia WD, Probosari N, Sulistiyani. Perbedaan OHI-S DMF-T dan def-t Pada siswasekolah dasar berdasarkan letak geografis di Kabupaten Situbondo. e-Jurnal Pustaka Kesehatan 2014;2(1): 35.

7. Sari SAN, Efendi F, Dian P. Pengaruh pendidikan kesehatan metode simulasi menggosok gigi Teknik Modifikasi Bass dengan keterampilan dan kebersihan gigi mulut pada anak MI At-Taufiq Kelas V. Indonesian Journal of Community Health Nursing. 2012;1(1):1.

8. Putri IN, Ilyas M. Efek penyuluhan metode demonstrasi menyikat gigi terhadap penurunan indeks plak gigi pada murid kelas VI Sekolah Dasar di Desa Padang Loang Kecamatan Patampanua kabupaten Pinrang. [diakses 4 mei 2015]. Diunduh dari: http://repository.unhas.ac.id/handle/1 23456789/2448

9. Notoatmodjo S. Promosi kesehatan teori dan aplikasi. Jakarta: Rineka Cipta, 2005; p. 286.

10.Nurhidayat O, Tunggul EP, Wahyono B. Perbandingan media power point dengan flip chart dalam meningkatkan pengetahuan kesehatan gigi dan mulut. Unnes Journal of Public Health. 2012;1(1):33.

11.Efendi F, Makhfudli. Keperawatan kesehatan komunitas teori dan praktik dalam keperawatan. Jakarta: Penerbit Salemba Medika;, 2009; p.111-3.

12.Efendi F, Nursalam. Pendidikan dalam keperawatan. Jakarta: Penerbit Salemba Medika, 2008; p. 220-1. 